\title{
Shifting memories and forced migrations: the Somali Zigula migration to Tanzania
}

\author{
Francesca Declich
}

This article is based on a comparison between a collection of memories of the past recorded in 1988 with a group of Zigula from the River Juba in Somalia and those gathered when I later followed the Zigula and Shanbara during their forced migration from Somalia. In 1992, civil war in Somalia led to warfare along the southern part of the River Juba. Many Zigula and Shanbara escaped to Tanzania (Declich 2010) and to Kenya, where the refugee camps of Dadaab hosted 10,143 of them in 1993-94 (Declich 2000: 27). This article tackles the way in which memories of the past have been shaped as a result of this latest forced migration and the events that occurred in the receiving country in the following years. While it is usually believed that changes in oral historical tradition occur randomly in many directions for political reasons (Handler 1984: 1026), especially in times of crisis (Hobsbawm and Ranger 1983: 1-2), I show how the rationale, shape and content of stories of the past have changed during specific migrations. Maurice Halbwachs described the way in which collective memories become shaped and suggested that 'we can understand each memory as it occurs in individual thought only if we can locate each within the thought of the corresponding group' (Halbwachs 1992: 53). Social historians have later seen memory as 'an ongoing interpretation of the past through an incessant selection, elision, and organization of data ... common to both professional and popular historians, to individuals as well as to collective groups' (Larson 2000: 287). Here, I share Larson's concern with recognizing the 'diversity of remembering and forgetting' and the richness produced by exploring different 'modes of memory' that emerged in the diaspora as these may offer valuable additional information in forming our perspective on African modern identities (ibid:: 279). Modes of memory may include discursive narratives and non-discursive practical forms of remembering (Shaw 2002: 49-50), as also shown in the gendered character of the memories of war violence (Declich 2001). My initial questions were: does the process of producing collective memories in a context of migration differ from the process underlying the production of memories at other times? And, if so, what are the peculiarities of producing memories in a context of migration? Do mechanisms of producing memories about the past change in times of migration, and, if so, how?

\section{The Zigula and Shanbara by the River Juba}

The Zigula who lived in southern Somalia in 1988 were a group of approximately 25,000 Kizigula-speaking people inhabiting approximately thirty villages (Declich

\footnotetext{
Francesca Declich is Associate Professor at the University of Urbino Carlo Bo. She has carried out long-term ethnographic fieldwork and archival research in Somalia, Tanzania and Mozambique and with Somali refugees in East Africa and the US. Her latest edited book is Translocal Connections across the Indian Ocean: Swahili-speaking networks on the move (Brill, 2018). Email: francesca.declich@uniurb.it
}

(C) International African Institute 2018 
1995a: 120). They had presumably arrived towards the end of the eighteenth century or the beginning of the nineteenth century, as Zigula are reported to have lived along the River Juba for approximately seven decades before the 1865 von der Decken exploration of that river (Kersten 1871: 303). A group of them had reportedly all escaped from slavery together. At the time of my visit to Somalia in the 1980s, their Bantu language was the only one still widely spoken by a large group of people in villages on the right bank of the river (Declich 1995a; 2002: 24). My early fieldwork among the Shanbara and the Zigula of the River Juba, which was carried out in southern Somalia between 1985 and 1988, involved recording the stories of their origins (Declich 2002; 2000; 1995a). The Shanbara, those inhabitants of the Gosha (i.e. the forest) area who speak the Somali language, reported slightly different versions of the past to those given by the Kizigula speakers. At the end of the nineteenth century, the Shanbara had gathered under the protection of Chief Nassib Bundo (Declich 2002). The earlier collective memories of both groups resulted from an experience of forced migration: they reported having been enslaved and brought by ship either from Unguja, on the coast of present-day Zanzibar, or from the port of Kilwa Kivinje. The Zigula also recalled the ways in which they had arrived along the River Juba, escaping enslavement in the town of Brava, on the Somali coast. In 1988, knowing of my anthropological interest, my local research assistant suggested I listen to several Zigula elders and record them. $\mathrm{He}$ and others in the village wanted someone to document the stories of the Zigula ancestors who, despite being dragged from the coasts of Tanzania, taken by force or tricked into slavery, had displayed impressive skills in managing to control and organize a free territory along the Juba.

When analysing the narratives created by the descendants of the forced migrants, I discovered that there was a difference in the way in which men and women relayed the story of their journey and escape from slavery. The women stressed the role of the female prophet/leader Wanankhucha, who planned and led their flight from slavery. She was regarded as the main figure in the female initiation ritual, the buinda. Some men also talked of this important figure, who had prophesied that the Zigula would have to settle in the Gosha area of the River Juba. However, other men highlighted in their narrative the role of a brave hunter and warrior, Majendero, who led the fugitive group before being killed by the Bon, as the local hunters are called, after which Wanankhucha took the lead. Other men's version of the story emphasized the importance of their own matrilineage, the kolwa (Declich 1995a). In fact, this group of men claimed that Wanankhucha had planned the escape together with the male leader Mze Migwa, identified by the name of his matrilineage, i.e. migwa, rather than by his personal name, which was Zando (ibid.: 114).

Soon after the Zigula were forced to leave Somalia, from 1992 onwards, I returned to interview them in their new location as refugees in Mkuiu, near Handeni in Tanzania. I found that old stories of the flight from slavery had changed somewhat. My aim in this article is to explore the motivations behind these changes and to examine the way in which memories of migrations are negotiated in a receiving country. In sum, having had the chance to familiarize myself with bodies of cultural memory of the Somali Zigula as they were before the migration caused by the war in 1992, I attempt to uncover what happened when this 'memoryscape' (Argenti and Röschenthaler 2006: 40) was 'transposed 
through space and place, and contested by different communities' (ibid.: 40) in a context of dramatic forced migrations.

\section{After 1992}

After the 1992 flight of the Somali Zigula from the River Juba to Kenya and Tanzania as war refugees, I spent several months, between 1993 and 1998, doing fieldwork in the Dadaab refugee camps in Kenya, the refugee settlement of Mkuiu, and among the early Zigula migrants in Dar es Salaam. ${ }^{1}$

I found at least three exemplary cases in which people tried to make sense of their present difficulties as refugees by recounting stories of the past. Each case, I believe, describes the construction of collective memories in a context of migrations and shows the patterns of the changes to such memoryscapes in exile. The most striking case refers to the way in which gender roles are negotiated through the reshaping of collective memories of the past. This case shows how women are losing symbolic power in the context of modern political systems. The second example relays a modified version of the escape from slavery through new details that help the audience make sense of their new political reality, and which are added according to modalities peculiar to a certain East African cultural area. The third case points to how stories of the past are used to interpret the present.

\section{The heroine Wanankhucha becomes a man ... in Swahili and in English}

I gathered the data in Tanzania in the years immediately after the Zigula forced migrants had reached Tanzania from Somalia. The main group arrived after escaping the war in Kisimayu in 1992 (Declich 2010: 175). People had recently reached the refugee settlement of Mkuiu, approximately 15 kilometres from the small provincial capital of Handeni in north-eastern Tanzania, and there were continuous new arrivals from Somalia or from the Dadaab refugee camp in Kenya, as well as groups of people who decided to go back to Kenya.

The group of war refugees, who had all arrived together in the town of Tanga (a port on the northern coast of Tanzania), had asked the provincial authorities that they be recognized as former Tanzanians returning home, as they were descendants of former Zigula slaves captured in Tanzania two centuries earlier. The Tanzanian government, despite recognizing that their ancestors had been subjected to displacement, decided not to grant them Tanzanian nationality and granted them asylum as Somali refugees instead (Declich 2010). This allowed the government to claim international aid through the UNHCR in order to set up support services for them; moreover, this also ensured that, should a much larger number of Somali Zigula leave Somalia for Tanzania as a response to push and pull factors, the government would be able to claim the resources to receive them.

\footnotetext{
${ }^{1}$ I carried out additional fieldwork in Tanzania after 1998, but my presence in the field was more frequent between 1993 and 1998.
} 
In those initial years of settlement, then, the Somali Zigula elders who had migrated from Somalia to Tanzania frenetically lobbied Tanzanian Zigula politicians. Having made contact with some Somali Zigula who had migrated to Tanzania in the 1960s and 1970s, before the war, they often discussed their integration in Tanzania with Zigula members of the Tanzanian parliament: the Somali Zigula wanted secure fertile land for their permanent settlement, good education and the chance to be involved in politics in Tanzania as citizens. They considered the Tanzanian Zigula members of parliament their representatives in Tanzania. One of Tanzanian president Julius Nyerere's close assistants was a Zigula and they were aware of the political importance of being in touch with members of parliament. $^{2}$

In Tanzania, members of parliament come from the region of their fellow citizens who speak the same local language. The elders of the Somali Zigula, even though they were born in Somalia, acted on the assumption that they could be considered citizens in their own right. They spoke Kizigula, and, as long as they were able to present themselves as an interest group speaking the same language as the members of parliament they approached, they thought they could succeed. They had very good personal relationships with some Zigula members of parliament and relevant state functionaries, including, at the time of my research, the MP Mze Jabir Kigoda (who had a residence in Handeni) and the judge Mze Mako Kimicha, both of whom I met. For their part, parliamentarians and Tanzanian Zigula intellectuals made a number of attempts to mediate between the needs of the interest group of Somali Zigula speakers and the wider Tanzanian national interest. Following the first allocation of Zigula to the refugee resettlement of Mkuiu, an area for the permanent settlement of the Zigula was found in Chogo, less than 10 kilometres east, on the B1 main road linking Mkata to Korogwe, several kilometres after the crossroad for Handeni. They declared that it was a fertile area, and in 2002 the refugees from Mkuiu were requested to move there.

Chogo, the allocated area, was uninhabited and covered with bush. The new refugees slashed and burned the vegetation, not only to cultivate crops but also to build new housing. The idea, therefore, was to develop a previously abandoned area by taking advantage of their manual labour. Drinking water was brought from the aqueduct of Korogwe: this needed repairs and the government thought that the new settlement of Somali Zigula could be used to argue for investments for the required infrastructural work. The presence of a group living in the area might encourage this improvement and other development activities, given the entrepreneurial attitude of the refugees from Somalia.

The Zigula judge Mako Kimicha lived close to the neighbourhood of MtoniMtongani in Dar es Salaam. One day in July 1995, a meeting was organized at his home for me to interview him about the Zigula from Somalia. ${ }^{3}$ I had expected to ask him what he thought of the Somali Zigula migration, his view on the organization of a permanent settlement for them and on granting citizenship to this group, and what the government planned for it. Instead, the meeting had been

\footnotetext{
${ }^{2}$ Contact with President Julius Nyerere had been made in Somalia shortly before its independence (Declich 2010).

${ }^{3}$ The meeting was held on 9 July 1995.
} 
organized in a different way and I found myself following the agenda of the Somali Zigula and the judge.

We all sat in a circle in the compound of the judge's home, myself and the judge on individual chairs while the other four people present were on less formal benches or stools. ${ }^{4}$ Some men started recounting the story of the Zigula, of the way they were brought from the coast of what is now Tanzania to Somalia well over a century earlier. There was a famine, they had gone to search for jobs along the coast, they were invited to load dates onto a boat, and once they were on it the ship sailed away. I had heard this story over and over again in Somalia with slight changes to each version, and I was annoyed that they wanted to repeat it to me, given that, among the 'foreigners', I probably knew it better than anybody else. However, I continued to listen to their narration. The escape had been organized by Majendero, who met other enslaved people in the bush during their days off work and, gradually, they constructed bows and arrows together. They also cast spells to protect them during their flight. One day they asked their masters if they could organize a dance party and travel from village to village; when they were in the farthest village, at the end of the day, they ran away. The woman prophet (ngonezi in Kizigula) Wanankhucha led the group when Majendero was killed, by which time they were already close to the River Juba. Notably, once they arrived in the locality called Buira (Mdame), which is not far from the present town of Jamaame in Somalia on the Juba River, the land started shaking. Wanankhucha led a $m v i k o^{5}$ ceremony by killing a wild fowl (instead of the usual chicken sacrificed nowadays for this particular ceremonial purpose) and she uttered a prophecy. The time for travelling was over and the Zigula should settle there, close to Buira, on the Juba. Had they continued travelling, they would have been punished by not being able to continue their journey.

When the story came to the contents of the prophecy, I heard something I had not heard before in Somalia: apparently, Wanankhucha had warned the Zigula that those who agreed to remain on the banks of the Juba would enjoy peace for seven generations, and only after that would they travel back to Handeni. This narration continued, listing, in order of progressive generations, Chinyaka, Muenyogono, Muia, Bilali, Athmani and Haji. The man named Chinyaka was one of the men who had escaped from slavery together with Wanankhucha. He was her companion. The children of Haji, the grandson of the narrator, Athmani, were part of the generation who had had to leave the River Juba in Somalia because of war.

An appendix to the story - containing warnings and forecasting punishment for whoever travelled away from the River Juba despite Wanankhucha's prophecy already existed in Somalia. It was said that those who did not believe the prophecy travelled south towards their country, but they were stopped by a plague that was decimating the inhabitants of the area they needed to cross, near the border of Somalia with Kenya.

\footnotetext{
${ }^{4}$ The people present were Abdullahi Haji Muia (thirty-seven years old), Mze Osmani Bilaal (seventy-two years old), Mze Mahmudi Jama (seventy-seven years old) and Hawa Hassani Mtungi (in her late thirties or early forties).

${ }^{5}$ Mviko is a celebration often involving the sacrificial killing of an animal for the ancestors.
} 
In Tanzania, two important new parts were added to the Somali prophecy. First, there were seven generations of peace until the Zigula would finally and decisively leave the River Juba, because of the war. This sounded particularly odd to me because, in Somalia, the Somali Zigula talked about the wars they had to fight in order to gain complete control of the territory along the river. In fact, these were recalled as the seven wars of the Zigula. The cycle of wars ended with the Zigula defeating the Somali people led by Sheikh Mambulo. As will be seen below, this was an example of the use of memories of the past to justify the present. Second, a new list of names was added of the seven men, together with a companion of Wanankhucha, Chinyaka, as their ancestor, who form a line of male descendants following whose demise the Zigula are destined to come back to Somalia. The seven men were not the same ones as in the earlier version of the story recounted in 1951-52 (Grottanelli 1953: 254-7) and later in 1988 (Declich 2002: 11). Back then, in Somalia, the genealogy most commonly reproduced was that of Mkomwa Mwaligo and his sister Mamgala Mwaligo. In fact, many people, in one way or another, reconnected their relatives to those important ancestors of the Zigula who had been born not in Somalia but in their original country. Mkomwa Mwaligo had been the Somali Zigula leader who signed agreements in 1891 with the Europeans trying to colonize Jubaland in southern Somalia. ${ }^{6}$ Those versions strove to certify people's origins outside Somalia, thus designating them as free people compared with other inhabitants who had only Somali ancestry and thus could not trace their origins to free people, although they could possibly trace them back to freed slaves (Declich 2017). Both of the new additions to the contents of the prophecy contained a legitimization of the present return of the Somali Zigula to Tanzania and their connection with those Zigula who, refusing to accept enslavement, escaped.

In other words, the recounting of prophecies pronounced in the past to legitimize present circumstances proved a common pattern in the narrative style of these origin stories. I also heard mention of an additional prophecy pronounced by Wanankhucha from two Somali Zigula elders shortly after the arrival of the Somali Zigula in Tanzania. ${ }^{7}$ In this version, Wanankhucha, when she made her mviko sacrifice at Buira (Mdame) after the escape from slavery, also forecast that another group, who were not to stop on the Juba but would proceed towards the west, would find another river. This group followed the prophetess Mamgasa $^{8}$ and they became the Shabelle people of the River Shebeli. The Shabelle are a group of farmers; they were probably among the earliest free inhabitants of the Somali rivers, and were later subjugated by the ethnic pastoral Somali (Cerulli 1934: 179). This version of the story was ostensibly produced in relation to the constitution of the political party SAMO, ${ }^{9}$ founded after the war

\footnotetext{
${ }^{6}$ Letter no. 19, Lovatelli to the Ministry of Foreign Affairs, Missione al Juba, Kisimayu, 25 July 1893, ASMAI (Archivio Storico del Ministero dell'Africa Italiana in the Ministry of Foreign Affairs), Pos. 55/6, Fasc. 42.

${ }^{7}$ Interviews with Salim Mwaligo, Dar es Salaam, 1994; Saladi Shebule, Dar es Salaam, 2003.

${ }^{8}$ This version is also reported in a book on the history of the Zigula produced after war broke out in Somalia in 1990 (Honero et al. 1999).

${ }^{9}$ The SAMO (Somali African Muki Organization) was founded in Somalia when President Siyaad Barre had lost his power and had left the capital city of Mogadishu and when the lineages of descendants or alleged descendants from slaves were co-opted into a war led by lineages
} 
in Somalia broke out in 1990. For the first time, this political party united members of all the groups of farmers considered descendants of slaves in Somalia - those who spoke Somali and who lived along the River Shebeli and the River Juba as well as the Zigula speakers in Somalia, often referred to as Mushunguli. The specific addition of prophecies pronounced in the past to forecast the success of a specific migration seems to be a distinct mechanism of memory construction among the Zigula. The contents of the prophecies may serve different purposes; in this case they justify or tend to assert local political statements.

The use of the past to justify the present situation is not only a narrative device that modifies myths of origins but is also a habit that mirrors a way of considering the rationale of certain events. This was clear when a man, in reflecting on the recent forced migration of the Zigula from Somalia, described to me the context of the present (1992 onwards) warfare in southern Somalia in contrast to the wars the Zigula had had to fight to acquire their territory in Somalia during the nineteenth century. The last of the Zigula wars, mentioned above, is remembered as the battle when the Somali ethnic fighters requested 'abur reeba', 'leave at least a seed of us'. This was an appeal not to kill all of them, since doing so would mean the extinction of the group. In that case the Zigula were merciful, accepted the Somalis' surrender and let them go (Declich 2002: 121). The man, now a refugee in Tanzania, said that the recent war of 1992 had been crueller than any other war with Somalis. He ascribed this violence to a revenge motive by the Somali Ogaden to pay back their foes for that ferocious battle led against Sheikh Mambulo. However, when reflecting on it, he still thought that it was too merciless a revenge. In this perspective, mentioning that 'seven generations of peace occurred in Somalia' is an important development of the narrative, which also emphasizes the much greater violence of the most recent war compared with the previous one. In this light, if appendices to prophecies tend to justify events that occur, it is most likely that a group of Zigula did in fact attempt to go back south and, having found a country disrupted by an epidemic illness, could not proceed on their journey.

Another important difference between the narration expressed in Tanzania and that from Somalia was evident during the meeting. Judge Kimicha expected my assistant to translate into Italian for me, but, as she did not, he stepped into the discussion and kindly translated into English part of the story that was being narrated in Kiswahili at that very moment: 'and he, Wanankhucha, made a mviko celebration and pronounced the prophecy that the Zigula should settle there'. In the Kizigula spoken in Somalia, the name Wanankhucha is restricted to females, meaning 'mother of a firstborn called Nkhucha': that is, in Kizigula, wana (the prefix used for mothers, and thus feminine) plus Nkhucha (name). This way of naming marks the stage in a married woman's life when she becomes a mother for the first time; the same stage of becoming a father is marked for her husband by being given the name of Sankhucha: that is, in Kizigula, sa (the prefix used for fathers, and thus masculine) plus Nkhucha (name). I turned to ask the lawyer whether he thought that Wanankhucha

considered 'noble' without gaining or being promised any benefits for their support. The party was active in early 1992. 
could be a 'he', at which point, without answering or even so much as batting an eyelid, he just changed the pronoun, recounting that 'she', Wanankhucha, made the mviko celebration pronouncing the prophecy. None of the three Zigula men and one Zigula woman present realized that, had I not known of their historical accounts in advance, a new masculine discourse of their past would have been authorized and publicized. In terms of the discussion put forward by Feierman (1990: 31, 33), and taking into account the arguments of Bourdieu (1987: 21) about who invests a form of discourse or practical activity with authority - a power game was at stake during that interview and the leverage was in the hands of a renowned lawyer.

There can be no doubt that Wanankhucha is a woman in a Somali Zigula context. There is an obviously gendered way of naming, using the prefixes wana- (feminine) and $s a$ - (masculine) before the personal name of one's firstborn baby. Among the Zigula in Tanzania, this habit of naming people, which clarifies their gender, has become obsolete. ${ }^{10}$

The judge perhaps thought that somebody who leads people away from slavery could only be a man, or that it would be more credible that Wanankhucha was a man, or simply preferred to see Wanankhucha as a man. On the other hand, as the Bantu languages do not have prefixes for the gender of a person, by translating from Kizigula he may just have made his choice about the gender of the leader. As the habit of naming men and women in relation to the first-born baby is no longer in common use in Tanzania, the local linguistic context allows for this gender shift for the main character in this legendary history.

The linguistic-cultural environment certainly had an important impact on the new development of the narrative. In fact, the judge's choice of the sex of Wanankhucha was not unique. The mutation from heroine to hero in the versions of the story of the escape from slavery reported in Tanzania also came to my attention in another interview some months earlier in the village of Mafuleta in the Handeni region. On that occasion, I thought it was just an oversight by the man I was interviewing in a very informal context, while I was driving a car. I was travelling with a Somali Zigula in order to witness, together with him, one of the most important rituals for the Zigula, the chisaza, and to compare its performance in Tanzania with the version performed in Somalia. I also asked what the Tanzanian Zigula thought about the Somali Zigula and their place of origin. In answering this question, a Tanzanian elder, Mze Mgaza Ngadala, ${ }^{11}$ recounted the story of the flight from slavery led by Wanankhucha, who, according to him, was a man. He thought that story was proof of the status of the Somali Zigula as Tanzanians, brothers and sisters of those living in the Handeni district. This story had become quite well known in the Mkuiu area after the arrival of the Somali Zigula in 1992; the refugees were generally well received by the local Zigula, who viewed this shared memory as an important testimonial of their trajectory into the Somali country after having left the coast of Tanzania on slave boats well over a hundred years earlier. All the Tanzanian Zigula officers I spoke with knew the story and mentioned it to me. So did other Tanzanian Zigula residents. Moreover, none of the Somali Zigula arriving from Somalia

\footnotetext{
${ }^{10}$ Interview with Mze Jabir Kigoda, Handeni, 15 March and 5 April 1994.

${ }^{11}$ Interview with Mze Mgaza Ngadala, Mafuleta, 20 October 1994.
} 
were unaware of this account, just as none of them were unaware of the name of their matrilineal affiliation, ${ }^{12}$ which coincided with those of the Zigula in Tanzania.

\section{Myth, history and gender shift}

There may be several explanations for this gender shift in the new historical version. It raises the question as to how far this was a change fostered consciously by the speakers. Unlike the Somali Zigula, those Tanzanians who recount the version with a male leader of the flight from slavery may not know her gender. This gender bias may, therefore, reflect the ignorance of the Tanzanian reporters rather than a concrete change in the social conditions of the Somali Zigula in Tanzania. The heroine Wanankhucha was a crucial figure in ritual contexts typical of the Somali Zigula. In the mid-1990s, the buinda female initiation rituals in which Wanankhucha is recalled as the powerful leader of the ritual were not held in Tanzania except by the Somali Zigula. Moreover, in Tanzania, unless they live in rural villages, even the Somali Zigula perform female initiations only in scattered houses in the urban marginal neighbourhoods of Dar es Salaam and less emphasis is given to dancing and the singing of Wanankhucha's songs. Obligatory schooling raises the age of marriage and also reduces the importance of female initiation rituals, which, in Somalia, usually take place only a few months or a year before a young woman's wedding.

The symbolic change that was occurring, which no longer established certain relevant female characters as role models, went almost unnoticed among younger and even older generations. In fact, in the twenty-first century there is no longer a very cohesive social context in which the oral historical version from Somalia can continue to reproduce the character of the female heroine, except in Chogo village. By the mid-1990s, the local Tanzanian society already preferred to see in Wanankhucha a male hero rather than a female one, as proved by the judge's choice and the local Handeni chief's testimony. In 2010, I spoke about the traditional rituals with some young Somali adult men and women who had been educated in Tanzanian schools. Amina, a young Zigula woman, who at the time of the interview had completed her studies up to the second year of teacher training through the financial support of her mother, showed no interest in the buinda female initiatory celebrations; she described them as unimportant traditions like many others in Tanzania, about which she knew little. Rather, she was concerned about formal education and aimed to go into a profession such as teaching or nursing or to continue with university studies. ${ }^{13}$ A young Somali Zigula, Yusuf, who had just completed his university degree in environmental studies in 2010, had his own explanation about the importance of the ritual celebrations in which historical memories are reproduced. He suggested that these were ways of strengthening the community; members feel refreshed and relaxed by dancing together. He was not particularly concerned with

\footnotetext{
${ }^{12}$ Names of common matrilineal groups are, among others, Chibindu, Lomwe, Mhandeni, Mneghero, Mswaghiro, Mvamira, Mwemulo, Mwenkumbi, Mweromba and Mwemulo.

${ }^{13}$ Interview with Amina Mkomwa, Dar es Salaam, July 2010.
} 
the meanings of the ritual songs - he probably knew few of them. ${ }^{14}$ Finally, another young man, Salim, who had not been able to study after the second year of secondary school, was disappointed by the fact that so few of his companions now pay attention to the meanings embedded in the ritual celebrations. According to him, as his mother had taught him, such celebrations were a sort of identity card confirming one's origins, and therefore were precious memories to be safeguarded, especially in times of migration. Being a member of a specific ritual dance and song meant, he said, proving one's origins. ${ }^{15}$ This is a position also taken by a number of elders in the Somali Zigula community; they know they are able to prove their 'Zigulaness' in Tanzania by speaking their original Bantu language, recounting the story of Wanankhucha and demonstrating their belonging to ritual celebrations of the matrilineal Zigula groups.

Ironically, memories about the prophetess Wanankhucha, which had been so important in legitimizing the arrival of Zigula 'brothers' from Somalia in Tanzania, have recently taken another course. Nowadays, new religious leaders have studied abroad and news about some radical Muslim trends pervading the Juba River region have reached the Somali Zigula settlement of Chogo in Tanzania. These leaders, during their speeches in the mosques, discredit as bid'a (religious innovations) both the traditional Zigula rituals and the traditional Muslim brotherhood prayers. Campaigns in schools against female genital mutilation and video broadcasts ${ }^{16}$ that warn young women against the performance of initiation rituals that can be used to hide the imposition of female genital mutilation contribute to the decreased importance of female initiation. In this context, it is more difficult for people to financially support the earlier large-scale female initiation ritual celebrations; some families prefer to organize smaller gatherings, and such rituals no longer convey prestige on female leaders as they did previously in southern Somalia and at the beginning of the Somali Zigula forced migrations in Tanzania. Young mothers well versed in dancing buinda do not take up the role of female initiation ritual leaders as it no longer enhances their reputation. The new Muslim religious trend, albeit from a completely different perspective, combines with the obstacles to organizing female initiation rituals deployed by Tanzanian schoolteachers. Consequently, far fewer young women know the story of Wanankhucha. ${ }^{17}$

The stories of the heroine Wanankhucha and the hunter Majendero as group leaders can be inscribed in a more general narrative pattern used to frame leaders of social change relating to migrations in this part of East Africa. An interesting argument to be re-examined with regard to changes, additions and the historical significance of legendary or mythical stories in this area of Tanzania is made by Steven Feierman (1974), who revisited the history of the Shambaa Kingdom. This was a centralized government ruled by the Kilindi lineage among the Shambaa of the Usambara mountains and which ended with the execution of the last Kilindi ruler by German colonial officials in the late 1800s. It is

\footnotetext{
${ }^{14}$ Interview with Yusuf Ahmed, Dar es Salaam, July 2010.

${ }^{15}$ Interview with Salim Osman, Dar es Salaam, July 2010.

${ }^{16}$ I watched one of those broadcasts on a television powered by solar power in August 2016 in Chogo.

${ }^{17}$ Interview with Athumani Mwale Macheremo, Dar es Salaam, September 2015.
} 
recounted that the first Kilindi ruler was Mbegha, a very skilled hunter who was in exile from the Ngulu people. The myths of Mbegha and Sheuta within the Shambaa, Bondei and Zigula of Tanzania go as far back as the era of the Kilindi. Feierman (ibid.: 67-69) asserted that the way the story of Mbegha is told shows an overlap with that of the legendary Sheuta, because, with changed conditions, historical meanings can be grafted onto a previous myth which can thereby change over time. In particular, he showed that the ruler, Mbegha, arrived in Shambaa at approximately the time the centuries-old ethnic unity of the Shambaa was being challenged by a large influx of immigrants from outside the region who did not share intimate, long-term cultural contact (ibid.: 71). This large immigration would also mark the beginning of a process of substituting Sheuta; Mbegha, the historical character, leader of the Kilindi, would be grafted onto the myth of Sheuta. Later, the story of Sheuta became progressively less well known.

According to the colonial officer Sadleir, Sheuta means 'son of the bow' in Kizigula and the name was bestowed on a legendary figure called Mganga who is reputed to have led his people in a guerrilla war against the Portuguese, teaching them for the first time the use of the bow and arrow as a weapon of war (Sadleir 1952: 91). ${ }^{18}$ Mbegha is also portrayed as a hunter who lived in the wilderness:

One day the women of Ziai were going down to the plains to collect firewood, and they saw the smoke of Mbegha's fire. Their husbands investigated and Mbegha assured them that he meant no harm and gave them gifts of meat. The people of Ziai reciprocated with gifts of starch. Because of his generosity, and because of his skill at killing wild pigs, he was welcomed by the Shambaa and taken to Bumbuli. He killed many wild pigs there and was given a wife in gratitude. Then the people of Vugha came to get him and he killed all the wild pigs at Vugha. Mbegha also helped to arbitrate disputes: people found that when he reasoned with the parties in dispute, they resolved their differences amicably. One night at Kihiti, near Vugha, a lion attacked some cows that were being kept in an outdoor enclosure. Mbegha appeared with his dogs and his spear and killed the lion. The following morning the Shambaa decided to make him chief of Vugha. (Feierman 1974: 43-4)

Such myths, in different periods, would have provided mythical and ritual justification for a social organization based on a patrilineal and patriarchal regime within the villages. The myth of Sheuta in particular represented domination of men over women (Feierman 1974: 68); in the narrative, Sheuta is appointed

${ }^{18}$ One part of the story of Sheuta goes like this:

A hunter who lived in a cave in the wilderness was befriended by a lion that shared its meat with him. Sheuta went hunting with his dogs and met an elephant that grabbed hold of Sheuta's penis and stretched it until it was long enough for Sheuta to sleep with the elephant. It then gave Sheuta a magical charm for making his penis longer or shorter at will. At this time, there was a woman named Bangwe who killed men once they had slept with her. Men from all over Shambaai were dying until Sheuta came and murdered Bangwe by lengthening his penis as he was having intercourse with her. The Shambaa were so happy at having rid the land of its scourge that they made Sheuta chief. He came through the wilderness from the south to an island in the middle of the river, in the land of women in which a woman was chief. Sheuta, naked, hid. He had with him his bow and arrows, roasted meat, and honey. ('Sheuta and the man-killing woman' in Scheub 2000; also available at <http://oxfordindex.oup.com/view/10.1093/oi/authority.20110803100501695>) 
chief in a land that was previously dominated by women, of which we know very little.

Sheuta has a place as a primeval masculine ancestor in basic sacrificial rites. These celebrations are performed in the three groups: the Shambaa, the Bondei and the Zigula (Feierman 1974: 66-7). This performance, according to Feierman, reinforced leadership by the heads of each of the patrilineal descent groups (ibid.: 68). Among the Zigula, this basic ritual is called ukala and is held before hunting expeditions. However, while the Tanzanian Zigula acknowledge the existence of Sheuta, who is recalled as a crucial ancestor within the ukala rites, the Somali Zigula in Somalia, who also held ukala rites before hunting, never mentioned the name of Sheuta to Grottanelli (1953), to me or to Menkhaus (1989); in fact, they did not know who Sheuta was. ${ }^{19}$ On the contrary, their best known mythical figure until the 1990s was the heroine Wanankhucha, whose name also recurred in the girls' initiation rituals as originating ancestor of the celebrations (Declich 2002: 211-12). The fact that the myths of Sheuta and Mbegha as masculine ancestors have been absent among the Somali Zigula in Somalia ${ }^{20}$ may suggest that such myths were related to a specific political formation in Tanzania and that this was politically reinforced at certain specific points in time - for example, after the diaspora of the Zigula speakers who arrived in Somalia: that is, possibly after the end of the eighteenth or beginning of the nineteenth century. While it is not possible to date such a diaspora with precision, we know, as mentioned earlier, that several Zigula were already living along the Juba River in Somalia approximately seven decades before 1865.

Certainly, the resonance of the myth of Sheuta in Tanzania was amplified during the 1950s, when the British colonial administration decided to appoint a paramount chief over the other chiefs (called zumbe) who were the heads of several chiefdoms in Uzigula. The title given to such a supreme chief was Sheuta, after the old Zigula hero. This occurred despite the fact that 'there were never chiefly paramounts in all Uzigula' before then (Beidelmann 1967: 68). In 1951, the provincial commissioner from Tanga, Mr Gill, marked the formal opening of a museum in Handeni in which a statue of Sheuta was unveiled (Sadleir 1952: 91). The statue had been manufactured by Paul Nkanyenka, then secretary of the tribal council, who had studied art at Makerere (ibid.: 91) and who was among the three founders of the political movement Moyo Zigula na $N g u u$, which aimed to defend the cultural and political identity of Kizigula speakers (Declich 2010: 179). ${ }^{21}$ Today, the character of Sheuta continues to resonate through its legendary history. In his present form he appears in a recent book written by Vincent Geoffrey Nkondokaya about the origins of the Wazigula, Wanguu, Wasambaa, Wabondei, Wakilindi and Waluvu of Tanzania (Nkondokaya 2003). ${ }^{22}$

\footnotetext{
${ }^{19}$ I conducted interviews about this in 1996.

${ }^{20}$ This has never appeared in the recollection of old historical sources collected by myself and by other scholars among the Somali Zigula in Somalia (Declich 1995b; 2002; Menkhaus 1989; Grottanelli 1953).

${ }^{21}$ For information about this movement, see Declich (2010: 179).

${ }^{22}$ During fieldwork in 1993 and onwards, I worked with Reynold Mfulo Nkondokaya, Vincent Geoffrey's father. We collected historical sources on the Tanzanian Zigula who had come into contact with the early Somali Zigula who migrated back to Handeni and data on matriliny in
} 
The changes in the myths reflected an important political change in the Shambaa area due to the overall political conditions created by a large migration of people. The figure of Mbegha entered Shambaai sometime in the eighteenth century, when the society was divided into two main ethnic groups and tensions had arisen due to these migrations (Feierman 1974: 72, 82). Feierman (ibid.) described the historical and political reasons for this shift in which a patrilineally driven political centralization appeared in an area otherwise characterized by small, self-sufficient political units that cooperated for exchange, defence and trade (ibid.: 78).

The stories of Sheuta and Mbegha seem older than that of Wanankhucha, and their historical implications are analysed by Feierman. The story of Wanankhucha in recent years has taken the form of a mythical or legendary foundation story, following similar patterns to those described for Sheuta and Mbegha. One can accept Feierman's point that important migrations of people may lead to changes in some forms of a myth. From this perspective, one would have expected some changes to the versions of the foundation myth of the Zigula of the River Juba, as indeed occurred. The directions of these changes, however, are not obvious and are interesting to study. The heroine Wanankhucha's gender change during the narrations I witnessed in Tanzania is occurring within the timeframe of my long-term fieldwork. The heroic role of the woman Wanankhucha is being erased, possibly due to the fact that in Tanzanian Zigula society the way of naming people according to matrilineal names is no longer in use, and also because of the fading of the practice of feminine initiation rituals. In the Swahili language, gender is not marked by prefixes or suffixes, and this language, shared by most people in Tanzania, plays a role in new memories of the past, paving the way for a new male discourse about the flight from slavery.

People, however, decode such memories according to the rules and cultural archive they know. The socio-economic context of southern Somalia is different from that of Tanzania, although the changes concern many aspects of life, not just matriliny. The feminine initiation ritual in which Wanankhucha was so central has become less important in Tanzania than it was in Somalia; the school schedule imposes a shorter period of seclusion for the female initiation rituals, and girls may already be at boarding school when they have the menarche. This discourages the performance of the rituals in these cases. School is compulsory and teachers do not allow pupils to leave the school for more than a few days. On the other hand, many urban Tanzanians no longer undergo female initiation. In other words, the ritual context that sustained and reproduced, in Somalia, the mythical character of Wanankhucha was rapidly losing importance in the mid1990s, leaving space for what Somali Zigula consider more modern Tanzanian habits.

Thus, to answer Feierman's question about the socio-political historical changes that led to changes in the myths, one could conclude that myths and legends travel with the people who migrate. Yet, they may be modified along the way, constituting, in Argenti and Röschenthaler's (2006) terms, part of the memoryscape of a group. There are specific narrative strategies, rhetorical

the surrounding area of Handeni. The father's research work certainly helped the son's publishing effort. 
forms, tropes and metaphors that are used in and based on certain cultural backgrounds. The changes depend not only on socio-economic and political conditions, but also on an interplay with the culture of the country of destination. The capacity of the recipient cultural environment to translate the myth into its own language both literally and metaphorically is at stake. For Judge Kimicha, a male hero is more justifiable than a female one and he prefers that version. For the man I met in the village of Mafuleta, a male ngonezi (diviner) is more credible than a female one. Both individuals translate in their own cultural terms the story they heard from the Somali Zigula. The Somali Zigula leaders of the girls' initiation ritual are not able to combat the trend in Tanzania that gives much greater importance to formal education than to certain forms of traditional education such as initiation rituals; their ability to give voice to the story is curtailed. Changes in 'women's rituals' in transnational migration have been relatively neglected (Gardner and Grillo 2002: 188), yet they may tell us much about the micro-level social dynamics within a group. In this case they reflect a change in the social prestige of the ritual's officiants and a growing prestige for those younger women who are able to get an education.

In sum, in Somalia the story of the heroine Wanankhucha was preserved through female initiation rituals that attested free origins among other descendants of slaves who did not speak Bantu languages and in a context where the elders of the Somali Zigula community - like the members of most Maroon societies (Price 1996) - guarded almost obsessively against being made slaves again. More recently, the escape from slavery, which, on arrival in Tanzania in 1993 was used as testimony to the authorities in Tanga that the Zigula were forced migrants of the nineteenth century who had escaped from slavery, is starting to be forgotten in present-day Tanzania. More than twenty years after their return to Tanzania as refugees (starting in 1992), the Somali Zigula have settled and no longer receive benefits from the state for their status as displaced persons; memories of migration are becoming less relevant to people's everyday lives. In fact, the history of migration is a source of mild embarrassment to young Somali Zigula adults as they prefer to present themselves as Tanzanians rather than Zigula refugees from Somalia, among other things in order to obtain easier access to jobs in the capital city.

\section{Narrative patterns and changes}

Feierman's study suggests that the mythical history of this area of Tanzania often portrays hunters, such as Sheuta and Mbegha, who succeed in freeing or helping their people by performing acts of divination and prophecy that support men's power and patrilineal leadership. This is a recognizable structural pattern in the construction of these myths. By contrast, the story recounted by the Zigula in Somalia a country where the use of a patrilineal idiom was a form of legitimization of the group in a patrilineally organized Somali environment (Declich 1995a: 113-14) involved the story of a hunter, Majendero, but also ascribed a crucial role to the feminine diviner Wanankhucha. The modification of this almost mythical story, effected during migrations in Tanzania in the 1990s, used a number of narrative tools.

The number seven, which in this case serves to highlight seven generations of people before a migration back home was allowed, already recurred as a trope 
in narratives of the history of the Zigula (Declich 2002: 120-4), and it may be considered a local paradigm of historical narratives. Codifying seven generations is considered a credible way to recount a series of events through time. Coupling Wanankhucha with a specific man in order to legitimize him or his matrilineage is another common pattern among the Zigula in remodelling narratives of the past. I have shown elsewhere a version of the story of the escape from slavery in which designating Mze Migwa - the man known by the name Zando - after his matrilineage name supported the importance of the matrilineal group migwa, to which the political leader who told me this version belonged (Declich 1995a: 114). Therefore, placing Chinyaka, the presumed companion of Wanankhucha, in the same position - the seventh generation - as is happening in the new Tanzanian version of the myth, is a specific political statement, this time identifying another genealogical group among the leaders. In sum, adding information to oral historical stories in order to remodel them occurs through certain specific paradigmatic narrative structures.

When discussing genealogies in Africa, focus has often been placed on their construction and the 'invention' of traditions. Constructing genealogies by including sometimes fictive ancestors or relatives not closely related by blood was considered a way to trick the audience into believing a false explanation of the past, usually for political reasons. In fact, this alleged false explanation often comprised a list of descendants of ancestral leaders placed 'incorrectly', or at least unexpectedly, in a certain genealogical line. The problematic assumption of this argument is that genealogies should always reflect blood ties and/or specific patrilineal or matrilineal connections.

Looking at the way in which the Zigula have represented different versions of their origins and in so doing have explained their forced migrations ${ }^{23}$ - from their journey into slavery from the port of Kilwa Kivinja or Unguja (Zanzibar) to the coasts of present-day Somalia (at the end of the eighteenth or early nineteenth century), to their escape from slavery from the town of Brava in Somalia (possibly at the very end of the eighteenth century or in the first decades of the nineteenth century) and their flight from the recent war in southern Somalia to Tanzania (from 1992 onwards) - one might reverse this reasoning. Constructing genealogies in a context of migration seems to be the core of a culture of mobility that is based on the idiom of kinship and utilizes its language. Genealogies are presented to show names of places, territories and people that can reconnect to others, and to create bridges with other groups of people. Emphasis on this or that ancestor, more often than not people who really existed, is given to show and assert relationships and connections. In fact, I suggest that, when viewed from the perspective of the Horn and East Africa, the idiom of kinship can be regarded as related to the need to cope with mobility rather than with stability. Although there is no space here to show other examples from Somalia, the nomadic Somali could be considered another crucial example of this. In a ground-breaking chapter, Abdallah Mansur demonstrated, by reporting a number of controversial genealogies, that 'the Somali clan structure typically is not based on blood relationship, but rather it is a fruit of

\footnotetext{
${ }^{23}$ The first one is the narration of the way in which they became slaves and then escaped from slavery two centuries ago, and the second concerns their arrival in Tanzania in 1992 because of the war in Somalia.
} 
nomadic pastoral life' (1995: 122). Schlee (1989) and Kusow (1995), each from a different perspective, also discussed the reasons underlying controversial genealogies. The different systems of adoption into patrilineal lineages such as the arifa and the sheegad, as described earlier by Zoli (1927: 178), Colucci (1924: 215) and Cerulli (1959), show that genealogies include adopted groups; later, Helander (1997: 137) found that in certain conditions Somali Rahanweyn can change their clan during their lifetime. In other words, genealogies appear to be more part of a culture of mobility than one reflecting the organization of people living in stable settlements.

The act of constructing genealogies helps to locate people of the past in specific times and sometimes in particular geographical spaces, especially when the names of the ancestors point to territories where the matrilineages were originally based. Those who claim to descend from any genealogical line assert their position in a specific social and, sometimes, geographical space. Among the Zigula, I have not witnessed discussions as to whether the names mentioned in a particular genealogy were real people; rather they are legitimately mentioned in the context of that genealogy. The act of recalling an ancestor is part of a process of evoking the past, which is usually done in groups of people to share collective memories or even to construct shared memories, and through the idiom of kinship. It is the context in which such eliciting is done that confers authority on the historical version recalled. The very fact that the Tanzanian judge organized a meeting for the public narration of this story of the origins of the Zigula, rather than holding a private conversation with me, shows the importance ascribed to the public elicitation of such accounts. The people who took part in the meeting with Judge Kimicha, whom I had heard at other times offering different versions of the story of Wanankhucha, did not dispute the version conveyed before the judge nor the new prophecy of Wanankhucha about their forecast arrival in Tanzania (in 1992 onwards) after seven generations of peace in Somalia. Evidently, the context in which the story was reproduced was considered authoritative and that was enough from their point of view.

The logic of constructing genealogies is not one of proving blood ties but one that, in contexts of frequent migration, aims to establish credible connections of relatedness (Carsten 2001), which are described according to the idiom of kinship, through lists of names of people down the generations, with a view to proving origins and legitimizing claims to territory. Such logics must be understood in a framework that assumes the likely mobility of the people in a territory rather than the certainty of their stability. In a way, they seem to be logical mechanisms used to cope with mobility well before the 'national order of things' was established (Malkki 1995).

\section{Conclusions}

In conclusion, I would like to come back to the questions I asked at the beginning of the article about whether there are some peculiarities in the memories of the past as recalled during migrations and if there are mechanisms that foster the construction of collective memories in contexts of mobility. It can be asserted that in this case construction or reconstruction of shared memories of the past, interwoven with mythical or legendary narrations, is part of a collective process of making sense of the migratory movement. While Casentini (this issue) describes ways in which memories grow and operate among migrants, I argue that a 
history of collective memories can be established and I attempt to trace how collective memories change according to certain patterns. In this process, interest focuses on the study of political and other motivations for specific representations and modalities that comply with specific local cultural patterns.

Having followed the Zigula before and during their exile through different stages of fieldwork from 1988 until very recently (2016), I have certainly witnessed, albeit to a limited extent, part of the very process of producing memories of the past in exile. In 2016, however, the spread of literacy, the prestige attached to formal education and the Tanzanian national policies against initiation rituals all seemed to override the symbolic power of mystical figures that used to be reproduced through ritual celebrations. In the 1990s, mythical accounts were still an important discursive context relevant to the success of the migration process. A judge and other authorities used the mythical stories to interact with Somali Zigula elders, mostly uneducated migrants. Mythical narrations played an important role in the integration of Somali Zigula among the rural literate Zigula speakers of the Handeni district in Tanzania.

Over almost thirty years ${ }^{24}$ in this specific East African context I have observed at least three different ways in which the narratives have been shaped. One is by appending new stories of clairvoyance to memories that justify the present situation. Even today, belief in prophecies spoken by special people is not in question. In this case, the addition makes the story of Wanankhucha one in which the diviner was able to forecast the return of the Zigula to Tanzania. This small change in the content of the story may seem, to a new observer, a useful narrative device for legitimizing the return of the Zigula and reasserting their 'Zigulaness' in Tanzania. For the Somali Zigula themselves, it is a story that helps assert their original membership of the Tanzanian nation: the elders had to convince the Tanzanian authorities of it (Declich 2010: 175-6). At the same time, this way of remodelling history reflects the manner of looking at the future among the Zigula. Foretelling the future through practices of divination and dreams is pervasive in this society and is not only done retrospectively. It therefore comes as no surprise that it is reflected in a story recounting memories of the past.

The second change concerns the gender of the actors of the stories, and has an obvious impact on the social status of both genders. Maybe the judge translated Wanankhucha as a man because he thought this would give more weight and legitimacy to the story. Or perhaps he simply thought that such a story could only pertain to a man. The fact that a shift in the gender of the characters involved in the stories is occurring, however, may open a broad discussion on the importance of oral histories and historical versions of the past for the socio-cultural construction of genders in a group of people. The erasure of the female actors reflects a shift in the sources of social prestige within Somali Zigula society in Tanzania; the public sphere in Tanzania is not pervaded by the performance of ritual celebrations to the same extent as the rural enclave of the matrilineal context of the Somali Zigula in Somalia. Access to formal education in Tanzania, which was not available in southern Somalia, introduced a new source of prestige among the Somali Zigula as it offers access to better-paid jobs for both men and

\footnotetext{
${ }^{24} \mathrm{My}$ observations extend from 1988 , the date of my early fieldwork on oral historical narratives, to 2016.
} 
women. A generation of Somali Zigula girls and boys, now in Tanzania, have dreamed of obtaining paid jobs as teachers. If memories relating to Wanankhucha fade from general awareness and the change from the feminine to the masculine gender of the legendary Wanankhucha finally becomes codified as shared memory, the importance of naming people after their firstborn may also become progressively less important in Somali Zigula society, together with the matrilineal way of naming individuals. Similarly, matrilineal characteristics have been forced into the background in Tanzania through a continuous colonial policy that enforced the empowerment of authorities traced patrilineally, and, subsequently, through policies of villagization (Declich 1996).

The third change occurs with the making or adjusting of genealogies for specific purposes. That genealogies are often constructed for political purposes has been widely explored in the anthropological and historical literature on African societies, yet the importance of such constructions, and their mechanisms, in the event of migration has not been explored enough. ${ }^{25}$ Often, the results of such constructions have been seen as a deviation from the norm. Yet, we should not forget that population movements have been an endogenous process within certain African countries. The Zigula, as well as other people of the same linguistic area, use the idiom of kinship to recount their past by constructing genealogies particularly during migrations - to describe and legitimize movements of people. As this allows for an explanation of the movements of people, and for migrants to be located in relation to their cultural site (Olwig and Hastrup 1997) and to establish forms of relatedness, one can very well consider it a form of culture of mobility.

\section{Acknowledgements}

This article is based on fieldwork carried out in Tanzania between 1993 and 1998, financed at different times through a World Bank scholarship programme, a postdoctoral grant from the Istituto Universitario Orientale of Naples and IFRA (French Institute for Research in Africa), as well as on follow-up research conducted in subsequent years until 2016. As dramatic events occur all the time in the process of forced migration, I kept updating information by following new events relating to war and the waves of refugees. The data concerning the production of memories, especially in the Tanzanian context of exile reported in this article, has not been previously published.

Thanks to the Refugee Studies Programme (RSP) of the University of Oxford, now Refugee Studies Centre, I was introduced to the Ministry of Home Affairs in Tanzania, which was helpful in granting me permission to visit and carry out research in the refugee settlement of Mkuiu. I am grateful to I. Kimambo from the Department of History of the University of Dar es Salaam for welcoming me whenever I approached him with queries and issues to discuss.

\section{References}

Argenti, N. and U. Röschenthaler (2006) 'Introduction. Between Cameroon and Cuba: youth, slave trades and translocal memoryscapes', Social Anthropology 14 (1): 33-47.

\footnotetext{
${ }^{25}$ An important exception is the work of Günther Schlee among the Somalis of northern Kenya (Schlee 1989). Also, Lee Vincent Cassanelli has recently been working on the rationale of the historical construction of Somali genealogies (personal communication, 2012).
} 
Beidelmann, T. O. (1967) The Matrilineal People of Eastern Tanzania (Zaramo, Luguru, Kaguru, Ngulu, Etc.). London: International African Institute.

Bourdieu, P. (1987) Outline of a Theory of Practice. Cambridge MA: Cambridge University Press.

Carsten, J. (2001) Cultures of Relatedness: new approaches to the study of kinship. Cambridge: Cambridge University Press.

Cerulli, E. (1934) 'Gruppi etnici negri nella Somalia', Archivio per l'Antropologia e l'Etnologia 64: 177-84.

Cerulli, E. (1959) Somalia. Diritto ed etnografia, linguistica. Come viveva una tribù Hawiyya. Vol. 2. Rome: Istituto Poligrafico dello Stato for the Amministrazione Fiduciaria Italiana della Somalia.

Colucci, M. (1924) Principi di diritto consuetudinario nella Somalia Italiana Meridionale. I gruppi sociali: la proprietà. Florence: La Voce.

Declich, F. (1995a) "'Gendered narratives," history, and identity: two centuries along the Juba River among the Zigula and Shanbara', History in Africa 22: 93-122.

Declich, F. (1995b) 'Identity, dance and Islam among people with Bantu origins in riverine areas of Somalia' in A. J. Ahmed (ed.), The Invention of Somalia. Lawrenceville NJ: Red Sea Press.

Declich, F. (1996) 'Unraveling women's history: coming back from southern Somalia to "Zigulaland" in Tanzania. What matri-kin do I belong to?' Paper presented at the Berkshire Conference of Women Historians, Chapel Hill.

Declich, F. (2000) 'Fostering ethnic reinvention: gender impact of forced migration on Bantu Somali refugees in Kenya', Cahiers d'Études Africaines XL: $25-53$.

Declich, F. (2001) 'When silence makes history: gender and memories of war violence from Somalia' in B. E. Schmidt and I. W. Schroder (eds), Anthropology of Violence and Conflict. London: Routledge.

Declich, F. (2002) I Bantu della Somalia: etnogenesi e rituali mviko. Milan: Franco Angeli.

Declich, F. (2010) 'Can boundaries not border on one another? The Zigula (Somali Bantu) between Somalia and Tanzania' in D. Feyissa and M. V. Hoehne (eds), Borders and Borderlands as Resources in the Horn of Africa. Oxford: James Currey.

Declich, F. (2017) 'Emancipazione degli schiavi nella Somalia del sud: fonti scritte e fonti orali tra mito e realtà', L'Uomo: Società, Tradizione, Sviluppo 2: 7-30.

Feierman, S. (1974) The Shambaa Kingdom: a history. Madison WI: University of Wisconsin Press.

Feierman, S. (1990) Peasant Intellectuals: anthropology and history in Tanzania. Madison WI: University of Wisconsin Press.

Gardner, K. and R. Grillo (2002) 'Transnational households and ritual: an overview', Global Networks 2 (3): 179-90.

Grottanelli, V. L. (1953) 'I Bantu del Giuba nelle tradizioni dei Wazegua', Geographica Helvetica 8 (3): 249-60.

Halbwachs, M. (1992) On Collective Memory. Chicago IL: University of Chicago Press.

Handler, R. (1984) 'General/theoretical: the invention of tradition by Eric Hobsbawm and Terence Ranger', American Anthropologist 86 (4): 1025-6. 
Helander, B. (1997) 'Clanship, kinship and community among the Rahanweyn: a model for other Somalis?' in H. M. Adam and R. Ford (eds), Mending Rips in the Sky: options for Somali communities in the 21st century. Lawrenceville NJ: Red Sea Press.

Hobsbawm, E. and T. Ranger (1983) The Invention of Tradition. Cambridge: Cambridge University Press.

Honero, A. H. et al. (1999) 'Zigula dya kaidi Somaliya'. Unpublished manuscript.

Kersten, O. (1871) Baron Klaus von Der Decken's Reisen in Ost-Africa in Den Johren 1862 Bis 1865. Leipzig: Vinter.

Kusow, A. M. (1995) 'Somali origins: myth or reality?' in A. J. Ahmed (ed.), The Invention of Somalia. Lawrenceville NJ: Red Sea Press.

Larson, P. M. (2000) History and Memory in the Age of Enslavement: becoming Merina in Highland Madagascar, 1770-1822. Oxford: James Currey.

Malkki, L. H. (1995) 'Refugees and exile: from "refugee studies" to the national order of things', Annual Review of Anthropology 24 (1): 493-523.

Mansur, A. O. (1995) 'The nature of the Somali clan system' in A. J. Ahmed (ed.), The Invention of Somalia. Lawrenceville NJ: Red Sea Press.

Menkhaus, K. (1989) 'Rural transformation and the roots of underdevelopment in Somalia's Lower Jubba Valley'. PhD thesis, University of South Carolina.

Nkondokaya, V. G. (2003) Asili ya waseuta. Yaani Wazigua, Wanguu, Wasambaa, Wabondei, Wakilindi na Waluvu. Makabila ya mkoa wa Tanga [series], vol. 2. Dar es Salaam: Peramiho Printing Press.

Olwig, K. F. and K. Hastrup (1997) 'Introduction' in K. F. Olwig and K. Hastrup (eds), Siting Culture. London: Routledge.

Price, R. (1996) Maroon Societies: rebel slave communities in the Americas. Boston MA: Johns Hopkins University Press.

Sadleir, T. R. (1952) 'A note on the Handeni Museum', Tanganyika Notes and Records 33: 91-2.

Scheub, H. (2000) A Dictionary of African Mythology: the mythmaker as storyteller. New York NY: Oxford University Press.

Schlee, G. (1989) Identities on the Move: clanship and pastoralism in northern Kenya. Manchester: Manchester University Press.

Shaw, R. (2002) Memories of the Slave Trade: ritual and the historical imagination in Sierra Leone. Chicago IL: University of Chicago Press.

Zoli, C. (1927) Oltre Giuba. Rome: Sindacato Italiano Arti Grafiche.

\begin{abstract}
Forced migrations, both now and in the past, imply a process of constructing and modifying accounts of past events, which become codified in memories. Memories are constructed to negotiate and reshape identity in the country of arrival. A number of factors interact in this process, some aspects are silenced and others emphasized, and new events may be invented. One of the arguments I make elsewhere is that, along the way, memories of the past, especially if gathered and codified through writing, may lose meanings that are unknown to the people who codify them. Yet, in times of forced migration, certain aspects of the memories re-emerge from the background and gain new relevance. This was the case, for instance, with matriliny and matrilineal names, which were not recognized or emphasized by those who codified certain oral traditions of migrations at
\end{abstract}


specific historical times in written form in Somalia. Yet, in the process of seeking integration in Tanzania after the forced migration caused by the 1992 war in Somalia, these aspects regained their importance in Somali Zigula memories and helped to achieve inclusion in the country of migration. Zigula memories of the past have undergone some changes. The way in which these changes have occurred is not unique: the process of modelling memories of the past that are based on idioms of kinship follows specific patterns that are part of a specific culture of mobility. Based on fieldwork carried out with refugees forced to migrate from southern Somalia to Tanzania in the early 1990s, I show how their collective memories of past events took on newly gendered features when circumstances changed and the main spoken language progressively shifted from Kizigula to Kiswahili.

\section{Résumé}

Les migrations forcées, tant aujourd'hui que par le passé, impliquent un processus de construction et de modification de comptes rendus d'événements passés qui deviennent codifiés dans les mémoires. Ces mémoires sont construites pour négocier et refaçonner l'identité dans le pays d'arrivée. Plusieurs facteurs interviennent dans ce processus, certains aspects sont réduits au silence et d'autres accentués, et de nouveaux événements peuvent être inventés. Un des arguments avancés ailleurs par l'auteur est le fait qu'au cours de ce processus, les mémoires du passé, surtout si elles sont recueillies et codifiées par écrit, peuvent perdre des significations qui échappent à ceux qui les codifient. Cependant, en période de migration forcée, certains aspects des mémoires refont surface et acquièrent une nouvelle pertinence. Tel fut le cas, par exemple, avec le matrilignage et les noms matrilinéaires non reconnus ou accentués par ceux qui ont codifié sous forme écrite certaines traditions orales de migrations à des moments spécifiques de l'histoire en Somalie. Hors, dans la quête d'intégration en Tanzanie après la migration forcée par la guerre de 1992 en Somalie, ces aspects ont retrouvé leur importance dans les mémoires des Zigua somaliens et ont aidé à parvenir à l'inclusion dans le pays de migration. Des changements sont intervenus dans les mémoires zigua du passé. La manière dont ces changements sont survenus n'est pas unique; le processus de modélisation des mémoires du passé basées sur des idiomes de parenté répond à des schémas spécifiques qui font partie d'une culture de mobilité spécifique. S'appuyant sur des travaux menés sur le terrain auprès de réfugiés contraints de quitter le Sud de la Somalie pour se rendre en Tanzanie au début des années 1990, l'auteur montre comment leurs mémoires collectives du passé ont pris de nouvelles caractéristiques sexospécifiques au gré des changements de circonstances et comment la principale langue parlée est progressivement passée du kizigua au kiswahili. 